\title{
Seismo-acoustic characterisation of the 2018 Ambae (Manaro Voui) eruption, Vanuatu
}

\author{
Iseul Park ${ }^{1,2,3}$ (1) Arthur Jolly ${ }^{2,4} \cdot$ Robin S. Matoza $^{5} \cdot$ Ben Kennedy ${ }^{1} \cdot$ Geoff Kilgour $^{6} \cdot$ Richard Johnson $^{6}$. \\ Esline Garaebiti ${ }^{7} \cdot$ Sandrine Cevuard ${ }^{7}$
}

Received: 26 February 2021 / Accepted: 20 June 2021 / Published online: 17 August 2021

(c) The Author(s) 2021

\begin{abstract}
A new episode of unrest and phreatic/phreatomagmatic/magmatic eruptions occurred at Ambae volcano, Vanuatu, in 20172018. We installed a multi-station seismo-acoustic network consisting of seven 3-component broadband seismic stations and four 3-element (26-62 m maximum inter-element separation) infrasound arrays during the last phase of the 2018 eruption episode, capturing at least six reported major explosions towards the end of the eruption episode. The observed volcanic seismic signals are generally in the passband $0.5-10 \mathrm{~Hz}$ during the eruptive activity, but the corresponding acoustic signals have relatively low frequencies $(<1 \mathrm{~Hz})$. Apparent very-long-period $(<0.2 \mathrm{~Hz})$ seismic signals are also observed during the eruptive episode, but we show that they are generated as ground-coupled airwaves and propagate with atmospheric acoustic velocity. We observe strongly coherent infrasound waves at all acoustic arrays during the eruptions. Using waveform similarity of the acoustic signals, we detect previously unreported volcanic explosions at the summit vent region based on constant-celerity reverse-time-migration (RTM) analysis. The detected acoustic bursts are temporally related to shallow seismic volcanic tremor (frequency content of $5-10 \mathrm{~Hz}$ ), which we characterise using a simplified amplitude ratio method at a seismic station pair with different distances from the vent. The amplitude ratio increased at the onset of large explosions and then decreased, which is interpreted as the seismic source ascent and descent. The ratio change is potentially useful to recognise volcanic unrest using only two seismic stations quickly. This study reiterates the value of joint seismo-acoustic data for improving interpretation of volcanic activity and reducing ambiguity in geophysical monitoring.
\end{abstract}

Keywords Volcanic tremor · Low-frequency infrasound · Ground-coupled airwave · Eruption detection · Tremor source depth

Editorial responsibility: A. Cannata; Deputy Executive Editor: L. Pioli

Iseul Park

ipark.volc@kigam.re.kr

1 School of Earth and Environment, University of Canterbury, Christchurch, New Zealand

2 GNS Science, 1 Fairway Dr., Avalon, Lower Hutt, New Zealand

3 Center for Mt. Baekdu Volcano Research, Korea Institute of Geoscience and Mineral Resources, 124 Gwahak-ro, Yuseong-gu, Daejeon 34132, Republic of Korea

\section{Introduction}

Basaltic eruptions are a dominant volcanism on Earth although the volcanic activity is mostly related to submarine volcanoes (e.g., Parfitt 2004; Siebert et al. 2010, 2015). Volcanic gas within basaltic magma may lead to explosive eruptions (Parfitt 2004) which represent a significant hazard

4 U.S. Geological Survey, Hawaii Volcano Observatory, Hilo, HI 96720, USA

5 Department of Earth Science and Earth Research Institute, University of California, Santa Barbara, CA, USA

6 GNS Science, Wairakei Research Centre, Taupo, New Zealand

7 Vanuatu Meteorology and Geohazards Department, Port Vila, Vanuatu 
to vulnerable island nations like Vanuatu. This study highlights the benefits of complementary campaign style seismoacoustic monitoring that is well integrated with the governmental response during an eruptive crisis. Manaro Voui (also called Aoba or Ambae) is a basaltic shield volcano on Ambae Island of the Vanuatu archipelago (Fig. 1a). It has been active since the late Pliocene or early Pleistocene (Warden 1970). The volcano has three crater lakes (Ngoru, Voui, and Lakua) at the summit and recently experienced various eruptions and degassing episodes from Lake Voui in 1995 (Global Volcanism Program 1995; hereafter GVP), 2005-2006 (Bani et al. 2009; Németh and Cronin 2009), 2011 (GVP 2013), 2016 (GVP 2018), and 2017-2018 (GVP 2019; Moussallam et al. 2019). The latest eruption episode began on 6 September 2017, with phreatic explosions that transitioned into Strombolian eruptions and lava effusion. Due to this increased activity, Vanuatu Meteorology and Geohazards Department (VMGD) raised the Volcanic Alert Level (VAL) to 3 indicating minor eruption. This episode ceased in late October 2018 and was divided into four phases. The brief timing of these phases is described in Moussallam et al. (2019) and GVP (2019) with slightly different time spans. During the 2017-2018 episode, the volcano displayed phreatic, phreatomagmatic, and magmatic eruptions with ash, steam, gas, and lava from Lake Voui, which led to an emergency evacuation of all residents to neighbouring islands in August 2018.

Research about Ambae eruptive activity is challenging due to its relatively remote location. Geological (Németh and Cronin 2009; Moussallam et al. 2019), geochemical (Bani
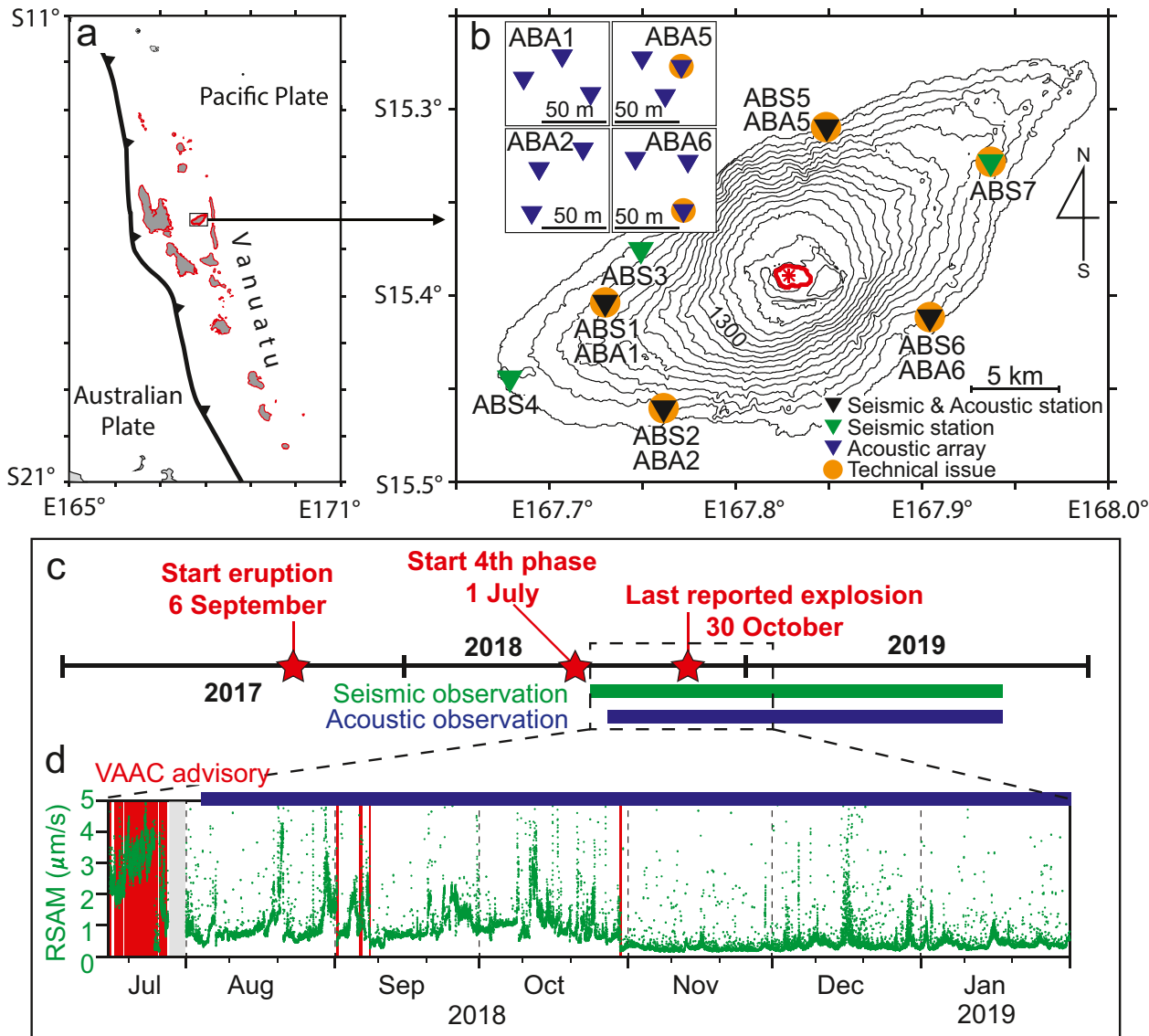

Fig. 1 a Location map of Ambae in Vanuatu with b contour map based on CGIAR-CSI SRTM 90-m DEM data. The contour intervals are 100 up to $1300 \mathrm{~m}$ and $50 \mathrm{~m}$ for higher elevation to denote lakes (the red line represents Lake Voui). The temporary seismic (ABS) and acoustic (ABA) network is indicated by inverted triangles, and stations having technical issues are denoted as circles behind the inverted triangles. An asterisk denotes the vent location at the summit. The inset figures indicate configuration of the acoustic arrays. c Timeline of the 2017-2018 episode and d RSAM $(\mu \mathrm{m} / \mathrm{s})$ for our observation period used in this study. The RSAM is computed using 10-min sampled vertical data recorded at ABS5, and detailed RSAM information is described in the "Seismo-acoustic data analysis" section. The key observations are indicated by stars in the timeline and vertical lines (VAAC ash advisories) in the RSAM data. The operation of seismic and acoustic stations marks green and blue horizontal bars, respectively. The tick marks on the RSAM time axis denote 1st, 10 th, and 20th of each month. The detailed operation of individual sensors for the early observation period is shown in Fig. S1. Most date are UTC with two exceptions (6 September 2017 and 1 July 2018) that have no detailed time information and provided as local time (Vanuatu time; VUT) 
et al. 2009), and seismic (Rouland et al. 2001) observations over the past two decades are related to the range of activity including the 1995, 2005-2006, and 2017-2018 eruption episodes. However, adequate understanding of eruptive behaviour and the drivers of volcanic activity is limited for Ambae. More broadly seismo-acoustic observations have become increasingly important for monitoring volcanic activity worldwide (e.g., Johnson and Aster 2005; Petersen and McNutt 2007; Jolly et al. 2014; Matoza et al. 2018, 2019a; Ishii et al. 2019). Hence, GNS Science (New Zealand) and VMGD collaboratively developed a science response project to aid in understanding of activity. A key aspect of this project was to explore the controls on the explosive eruptive behaviour at Ambae, resulting in a temporary deployment of a local seismo-acoustic network on the island to capture volcanic activity and support improved monitoring capabilities (Fig. 1b).

In this study, we investigate the general characteristics of seismic and acoustic (seismo-acoustic) activity at Ambae from July 2018 to January 2019, which partially includes the last phase in the 2017-2018 eruption episode. We thus examine volcanic activity associated with eruptions and the post-eruption period. Seismo-acoustic observations provide an opportunity to understand volcanic eruption dynamics and subsurface processes. To this end, we apply several standard processing techniques to this novel dataset. We obtain insights about the shallow conduit dynamics for an explosive basaltic eruption that is likely driven by extensive magma-water interactions.

\section{Eruption episode and temporary network}

\section{Eruption episode}

Ambae volcano entered the fourth phase of the 2017-2018 eruptive episode on 1 July 2018 (Vanuatu time; VUT) with an ash eruption followed by minor eruptive activity (GVP
2019; Fig. 1c). More intense eruptions of ash were reported from 16 July by the Wellington Volcanic Ash Advisory Centre (Wellington VAAC; Fig. 1d), with intense volcanic activity persisting until early August. As the activity proceeded, VMGD issued an alert level bulletin raising the VAL to level 3 indicating minor eruption (Vanuatu volcano alert bulletin $\mathrm{N}^{\circ} 7$ ) on 21 July 2018 (VUT). In August, the intensity of eruptive activity diminished (Moussallam et al. 2019), but minor emissions of gas/steam and ash continued (Vanuatu volcano alert bulletin $\mathrm{N}^{\circ} 8$ ). On 1,6 , and 8 September, four explosions with ash advisories were reported by the Wellington VAAC but by 21 September (VUT), the activity diminished and VMGD lowered the VAL to level 2. The last ash advisory was issued following a short-lived ash/steam explosion on 30 October 2018. Since then, no obvious eruptions have been identified except for gas-steam venting activity reported by VMGD volcano alert bulletins on 6, 7, and 21 January 2019 (VUT) (GVP 2019). Lava activity apparently ceased in October 2017, but MODVOLC thermal alerts were issued until 14 January 2019.

\section{Temporary network}

From mid-July 2018, GNS Science and VMGD operated the temporary seismo-acoustic network. Seismic activity was observed at seven 3-component broadband sensors (ABS1-ABS7) from 13 July 2018 to 25 September 2019 (Figs. 1 and 2). The portable seismometers recorded on local flash drives and were serviced approximately every 3 months. The seismic stations consisted of Nanometrics Trillium compact $120 \mathrm{~s}$ broadband sensors and Taurus digitizers. To minimise risk due to volcanic activity, the stations were located between 8 and $18 \mathrm{~km}$ away from Lake Voui, which may limit the capacity to detect some of the low energy seismic signals produced from the vent area. For the early operational period, only a subset of the stations was available due to a progressive schedule of the installation
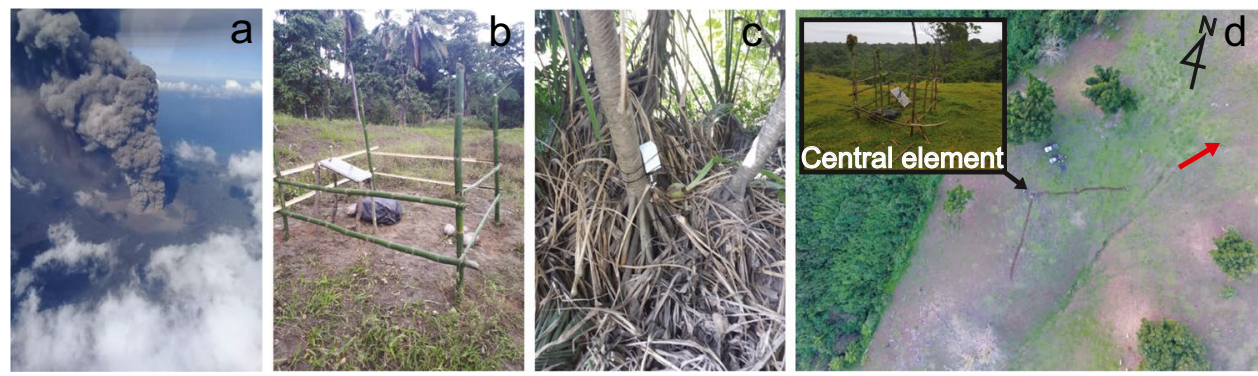

Fig. 2 a Aerial photo taken on 17 July 2017 (photo credit: Joshua Kaboha-Air Taxi Vanuatu). b Seismic sensor installation photos at $\mathrm{ABS} 3$ and $\mathbf{c}$ infrasound microphone at $\mathrm{ABA} 5$ array, respectively (photo credit: Arthur Jolly-GNS Science). d Drone image of ABA2 array and its central element collocated with ABS2 (photo credit: Richard Johnson-GNS Science). The red arrow points towards the vent 
for each station and subsequent recording problems (Fig. S1). The ABS1 sensor was significantly contaminated by low-frequency periodic noise, and ABS2 was often influenced by non-volcanic local sources. During the early observation period, ABS6 had a gain issue and ABS7 rarely operated. All seismic signals were sampled at $100 \mathrm{~Hz}$, and background seismic noise (Ocean microseism) has a peak frequency $\sim 0.2 \mathrm{~Hz}$.

Four acoustic arrays (ABA1, ABA2, ABA5, and ABA6) were also deployed from 4 August 2018 to 25 September 2019, and each array is comprised of three elements (Figs. 1 and 2). The infrasound microphones are InfraBSU (Boise State University) type with a flat response from $30 \mathrm{~s}$ to Nyquist, a sensitivity of $45.13 \mathrm{~V} \mu / \mathrm{Pa}$, and linear range of $\pm 124.5 \mathrm{~Pa}$ (Marcillo et al. 2012). Signals are sampled at $100 \mathrm{~Hz}$ on Omnirecs DATA-CUBE digitizers. The interelement distances range from 26 to $62 \mathrm{~m}$, and the central elements are collocated with the corresponding seismic sensors (Fig. 2d). One element of ABA5 was long-term gain and acquisition issues, and one of ABA6 was influenced by local noise. The technical and acquisition issues of seismoacoustic sensors rendered the sensors unusable for some observational tasks. We thus summarised a list including analytical methods and used stations in Table S2.

\section{Seismo-acoustic data analysis}

We investigated Ambae volcanic activity for the period between the onset of temporary network operation and the end of January 2019 (Fig. 1c) to capture possible seismoacoustic activity related to steam emissions. Because of the difference between operation periods for seismic and acoustic sensors, only the five reported ash explosions in September and October 2018 were recorded on both sensor types (Fig. 1c). Some explosions included two or three distinct pulses around the approximate eruption time given by the Wellington VAAC (Fig. 3).

Overall observation of seismic data suggests that the volcano generally produced tremor during periods of eruptive activity. These comprised the frequency range of $0.5-10 \mathrm{~Hz}$ with a dominant frequency of $\sim 1 \mathrm{~Hz}$ (Fig. 3). Volcanic tremor is often observed at active volcanoes before and during eruptions with amplitude and frequency variations (e.g., Battaglia et al. 2005; Chouet and Matoza 2013; Chardot et al. 2015; and references therein); hence, it is regarded as an essential tool to monitor volcanic activity (Alparone et al. 2003 and 2007). Its mechanism is generally related to volcanic fluid movement (e.g., Aki et al. 1977; Ferrick et al. 1982; McNutt 1992; Julian 1994; Konstantinou and Schlindwein 2002; Nadeau et al. 2011; Fee et al. 2017; Salerno et al. 2018). To examine temporal variations in tremor activity at Ambae, we computed "real-time" seismic a 1 September 2018
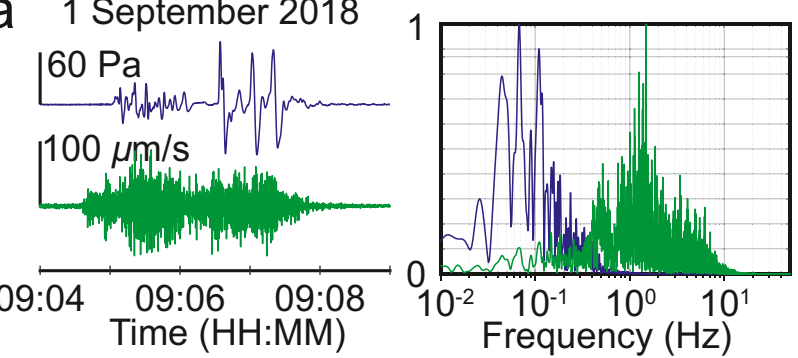

b 06 September 2018
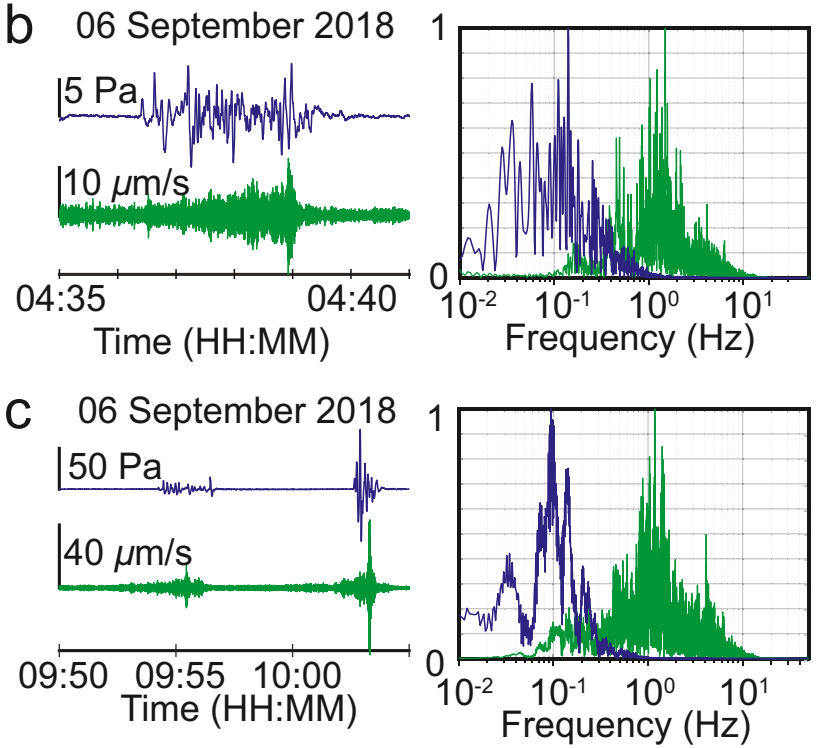

d 08 September 2018
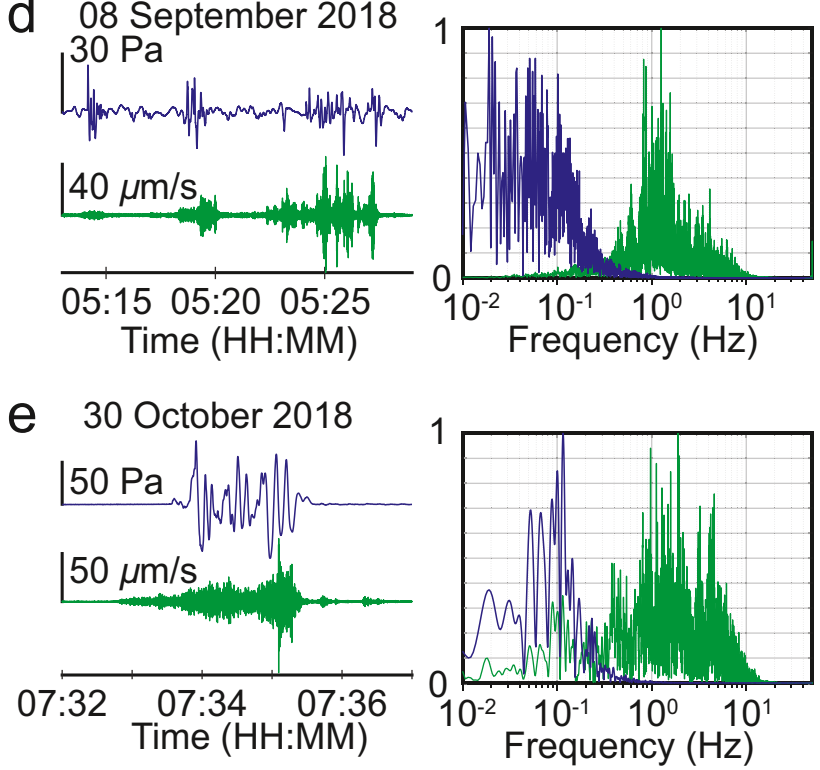

Fig. 3 a An example of acoustic (blue; ABA5) and seismic (green; ABS5) unfiltered waveforms and their normalised spectra for the five explosions on (a) 1 September, (b and c) 6 September, (d) 8 September, and (e) 30 October 2018 
amplitude measurement (RSAM; Endo and Murray 1991) using 10-min sliding window after filtering in the $0.5-10 \mathrm{~Hz}$ band (Fig. 1d). Tremor amplitudes vary over the observation period, but frequency content remains nearly consistent without remarkable changes although it is slightly different across stations. Elevated tremor activity dropped to noise level on 25 July 2018 and suddenly resumed with the largest explosion of 2018 on 26 July. The subsequent tremor activity diminished in early August 2018, and occasional activity lasted until 30 October 2018 when the last ash explosion was reported. Additionally, the RSAM data temporarily increased in mid-December 2018 due to an eruption and earthquake swarm activity around Ambrym Island located in about $100 \mathrm{~km}$ south of Ambae.

Acoustic observations were not available in July-early August 2018 when the intense volcanic activity occurred, whereas the five reported explosions in September and October 2018 were well recorded. The acoustic signals from Ambae are predominantly $<1 \mathrm{~Hz}$ (Fig. 3), and this low-frequency-dominant infrasound signal is unusual at volcanoes. Compared to short-duration impulse signals, cases are uncommonly observed associated with volcanic eruptions: e.g., Mount St. Helens in USA (Moran et al. 2008), Ruapehu in NZ (Jolly et al. 2010), Pagan in Mariana Islands (Lyons et al. 2016), Lokon-Empung in Indonesia (Yamada et al. 2017), Aso, Kuchinoerabujima, and Kirishima in Japan (Yamada et al. 2017), and Bogoslof in Alaska (Lyons et al. 2019; Fee et al. 2020). At Ambae, low-frequency signals are clearly observed in raw unfiltered seismograms during explosions (Fig. 3). At the frequency band of $0.02-1 \mathrm{~Hz}$, we computed corresponding "real-time" infrasonic amplitude measurement (RIAM) of 10-min data (Fig. 4). Unlike RSAM, the RIAM trends are possibly influenced by wind noise (including by a south-eastern prevailing wind direction) rather than volcanic activity (Fig. 4). The reported explosions are discriminated as distinct high amplitudes from the general RIAM trend. Their zero-to-peak pressures are 7-73 Pa at the central element of ABA5 located $9.1 \mathrm{~km}$ apart from the vent (Fig. 3). Their waveforms are composed of complex extended wave trains. Each explosion was recorded as highly coherent signals at the low frequency band $(<1 \mathrm{~Hz})$ throughout most acoustic arrays, which allow to be discriminated from incoherent wind noise.

\section{Method to check for air-to-ground-coupled waves in seismograms}

Acoustic waves emitted from volcanic explosions sometimes couple significantly with the ground. Observations and modelling to date indicate that air-to-ground coupling (propagating at acoustic velocity) is more common given volcanic source and velocity structure configurations than groundto-air coupling (propagating at seismic, e.g., Rayleigh wave velocity Matoza et al. (2009)), although both ground-air and air-ground coupling have been documented in seismoacoustic publications (Blom et al. 2020). Air-to-ground
Fig. 4 Ground-level wind information observed at (a) Pekoa weather station (red circle) at Santo Island located approximately $67 \mathrm{~km}$ away from the vent (red asterisk). b The hourly wind direction is measured in degrees clockwise from geographic north, and the speed is an average over 10 min immediately before the observation time. The data are provided by the Meteorological Service of New Zealand. A relationship between (c) acoustic signals and (d) wind speed. c RIAM (Pa) of $10 \mathrm{~min}$ sampled data computed using the central element of ABA5. The long-term trends in the RIAM data mostly coincide with (d) high-speed wind (HSW; $>10$ knots) although every HSW did not lead to strong RIAM (see in late November 2018). Diurnal noise (roughly at 6:30-18:00 VUT) is clearly observed at periods of low RIAM a

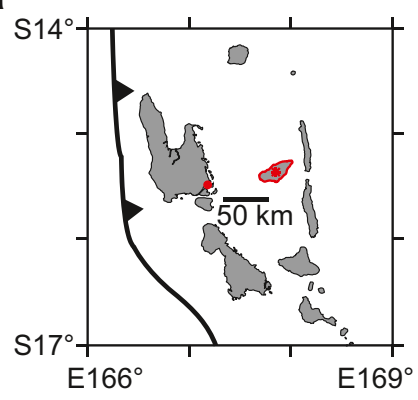

b
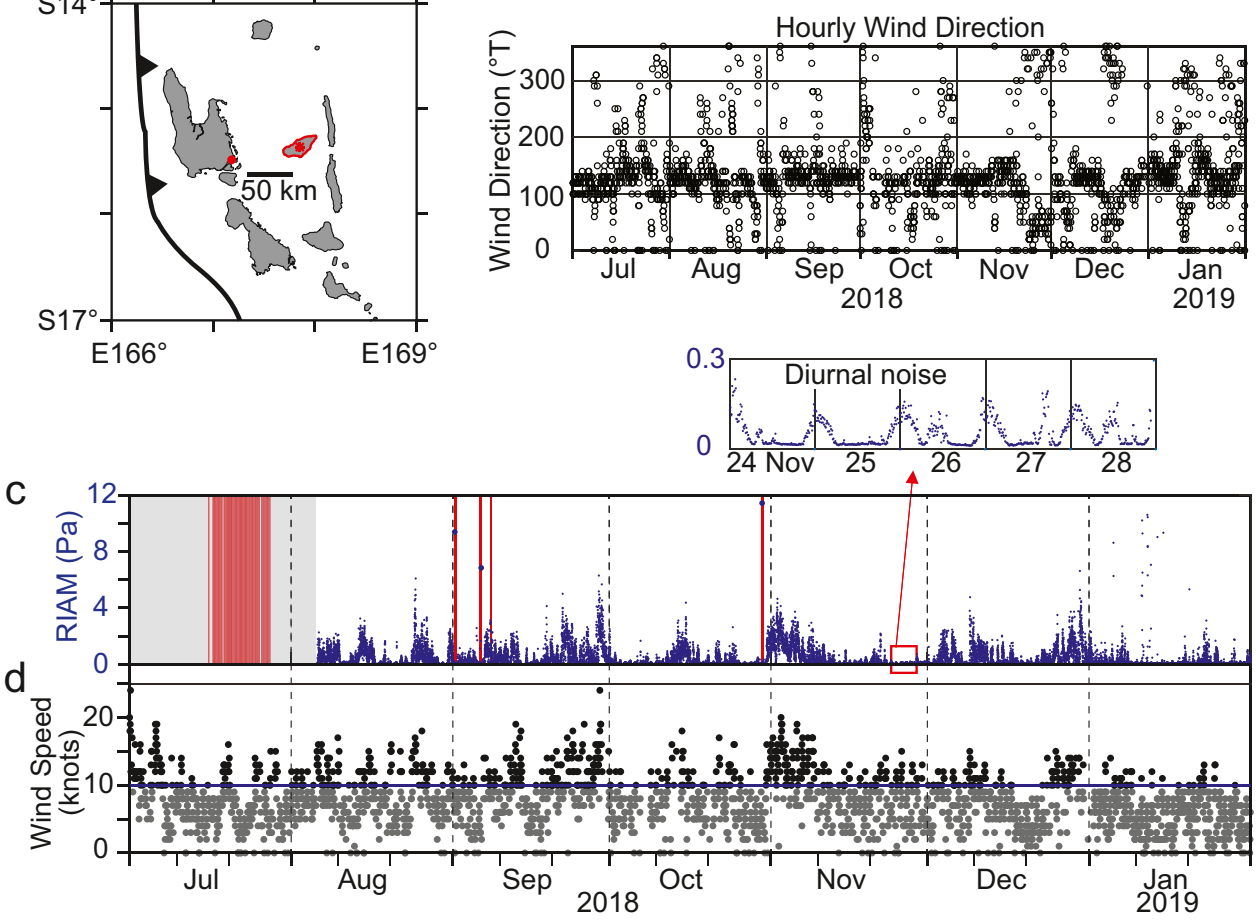
conversions or ground-coupled airwaves have been observed in local to remote volcano monitoring systems (Hagerty et al. 2000; Johnson and Malone 2007; De Angelis et al. 2012; Ichihara et al. 2012; Matoza and Fee 2014; Fee et al. 2016; Ichihara 2016; Nishida and Ichihara 2016; Smith et al. 2016; Matoza et al. 2018; Mckee et al. 2018; Haney et al. 2020; Kurokawa and Ichihara 2020; Sanderson et al. 2020).

To check for air-to-ground-coupled waves in seismograms, (1) cross-correlation (Ichihara et al. 2012), (2) coherence (Matoza and Fee 2014), (3) response function (Ichihara, 2016; Kurokawa and Ichihara, 2020), and (4) reverse-time migration (RTM) have been applied. Variations on the RTM method include back projection, stacking, source scanning, and time-reversal (e.g., Walker et al. 2011; De Angelis et al. 2012; Jolly et al. 2014; Sanderson et al. 2020). This approach is originally used to locate seismic (Ishii et al. 2005; Kiser and Ishii 2011) and acoustic (Jolly et al. 2014; Sanderson

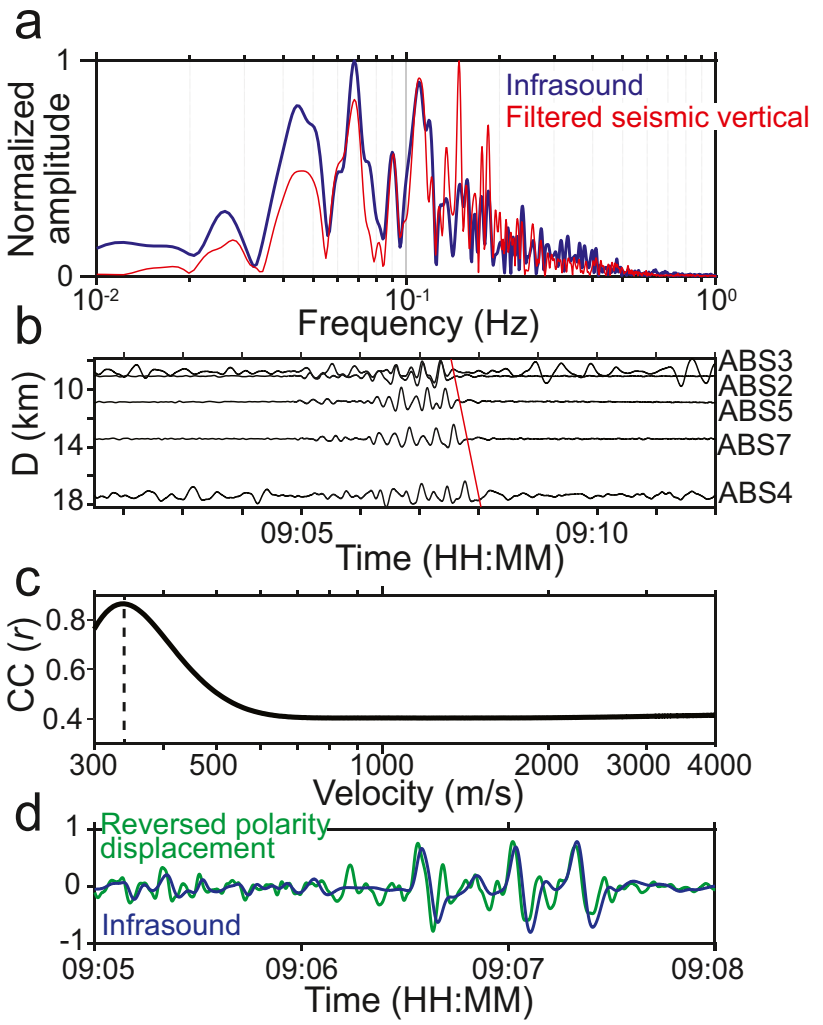

Fig. 5 An example of ground-coupled airwaves for the explosion on 1 September 2018. a Normalised frequency spectra of unfiltered acoustic (blue; ABA5) and low-pass filtered seismic (red; ABS5) waveforms and $\mathbf{b}$ the VLP band $(0.03-0.1 \mathrm{~Hz})$ seismograms. The velocity of $340 \mathrm{~m} / \mathrm{s}$ is indicated as the red line. c Average correlation-coefficients $(r)$ between the five seismic waves and their stacked waves after time-shifting to the vent using the given velocities ( $\mathrm{x}$-axis has $\log$ scale). High $r$ of 0.87 is observed at $340 \mathrm{~m} / \mathrm{s}$ (vertical dashed line) implying acoustic wave velocity. d Filtered infrasound (ABA5) and polarity-reversed vertical displacement (ABS5), and both amplitudes are normalised (amplitude scale factor $=31.5 \mathrm{~Pa} / \mu \mathrm{m}$ ) et al. 2020; Fee et al. 2021) sources related to volcanic eruptions, while here we identified the dominant propagation velocity across a seismic network. For the Ambae eruptions, the dominant frequency band of acoustic waves significantly differs from that of seismic tremor (Fig. 3). We note that a spectrum of seismic data in a very long period (VLP) band is nearly identical to that of unfiltered infrasound (Fig. 5a). We thus assume that seismic VLP signals are not related to subsurface volcanic processes and are highly contaminated by acoustic pressure induced from explosions. To test this hypothesis, we applied the RTM technique to the seismic VLP signals bandpass filtered at $0.03-0.1 \mathrm{~Hz}$ (Fig. 5b). This method simply stacks all seismic or acoustic waveforms after shifting and aligning travel times to a trial location within a designated area and then determines an optimal source position where the highest stacking value is observed. Jolly et al. (2014) additionally adopted an alternative way using the average correlation coefficient $(r)$, which is also applied here. To compute $r$, the aligned signals are stacked as the same way of the stacking RTM technique and then an average value is calculated using correlation coefficients between the stacked waveform and individual shifted signals. We fixed a source location at the vent to confirm only the propagation velocity. We then computed $r$ for the five explosions using trial wave velocities from 300 to $4000 \mathrm{~m} / \mathrm{s}$.

\section{Method to distinguish infrasound and non-volcanic noise}

We have ash plume information based on 67 volcanic ash advisories from the Wellington VAAC for our observation period, which were mostly issued in July except for the five explosions in September and October 2018. Aside from these reports, the RSAM and RIAM data imply additional potential explosions. To identify additional unreported explosions, we applied the RTM method to filtered infrasound signals in VLP band where most energy is concentrated (Fig. 3). Using the VLP waveforms allows us to obtain clean RTM results. At high frequency, the signals are less coherent and result in complicated RTM that are probably affected by topographic effects. Before application to the full acoustic time-series, we first analysed the reported explosions recorded using 11 elements. Source locations were searched within a $2 \mathrm{D}$ grid of $36 \times 25 \mathrm{~km}$ at the vent elevation with $500 \mathrm{~m}$ spacing under the assumption that the acoustic signals propagate at a steady velocity within a range of 310 to $370 \mathrm{~m} / \mathrm{s}$. Although variations in velocities were not significantly sensitive to location results because acoustic signals concentrate on low frequencies, we tried to determine an optimal sound speed. In general, the results show a strong correlation with $350 \mathrm{~m} / \mathrm{s}$ at the vent (Fig. S3). One example of the RTM results is shown in Figs. 6a, b, and c. We confirmed that acoustic source locations for the five 


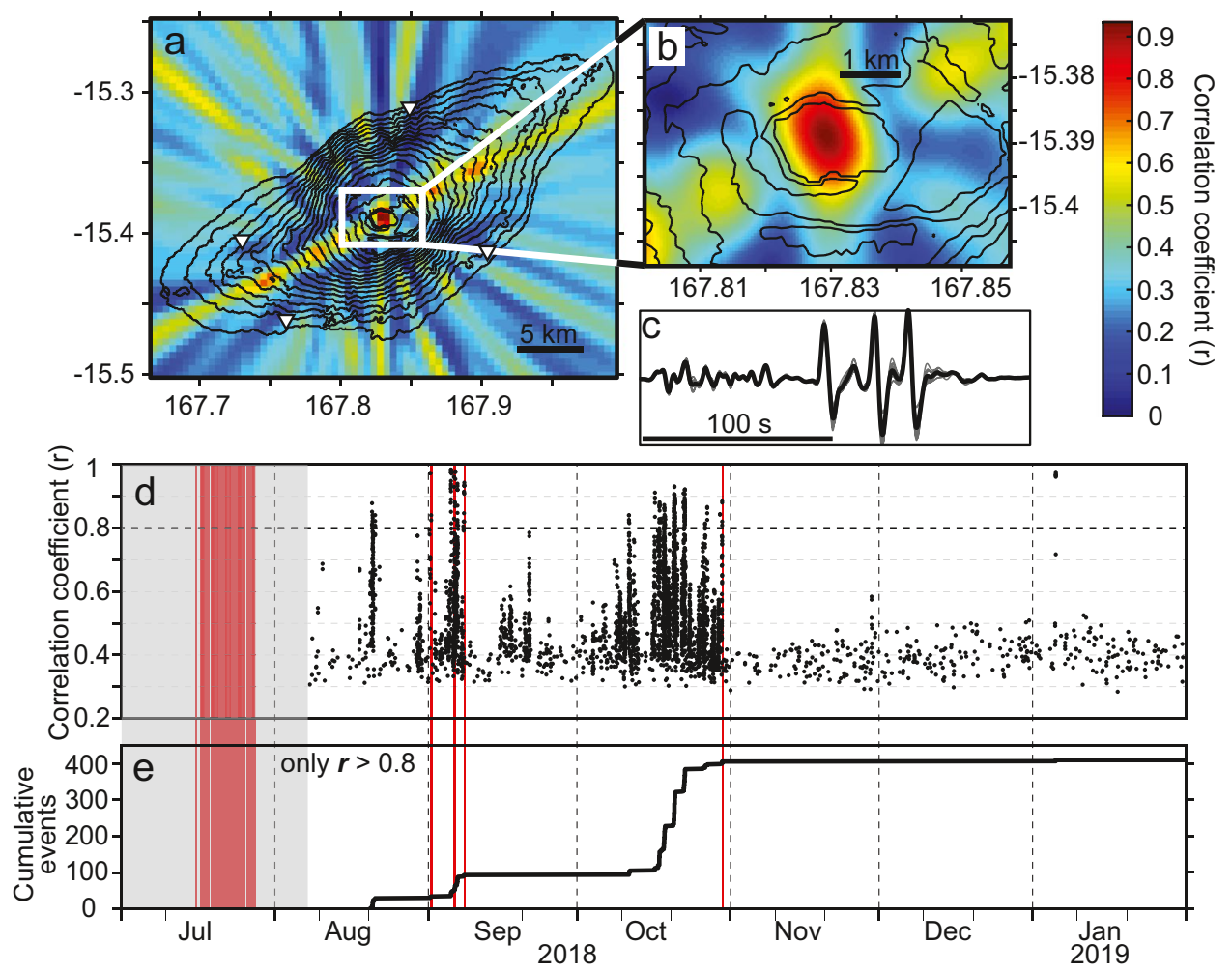

Fig. 6 An example of acoustic source location (red) for the explosion on 1 September 2018 from application of the RTM method using (a) coarse $(36 \times 25 \mathrm{~km}$ grid with $500 \mathrm{~m}$ interval) and (b) fine $(6 \times 4 \mathrm{~km}$ grid with $100 \mathrm{~m}$ interval) grid searching. $\mathrm{c}$ The acoustic waves of 11 elements (grey) shifted back towards the vent using the consistent propagation velocity of $350 \mathrm{~m} / \mathrm{s}$ and their stacked wave (black). These waveforms are filtered at a range of $0.02-0.1 \mathrm{~Hz}$ to minimise high frequency topography effects; hence, the results show high similarity ( 0.97). Detection results from the RTM approach for possibly unreported explosions are shown in $\mathrm{d}$ and e. Vertical red lines indicate the Wellington VAAC ash advisories. d Strong coefficients (arbitrarily set to $r \geq 0.8$ ) indicate potential volcanic explosions, and e the cumulative number of these explosions known explosions occurred at the same vent position with $r>0.89$ depending on signal quality.

The detection algorithm for potential volcanic explosions thus searched airwaves produced from the single vent. Acoustic waveforms within a 4-min moving window with $50 \%$ overlap for preventing potential non-detection were triggered from the continuous data if the signals have a maximum $r$ at the vent within a $6 \times 4 \mathrm{~km}$ grid. We also applied the RTM method to apparent seismic VLP (using an acoustic trial velocity assuming air-to-ground coupled waves) to detect possible explosions when only the seismic network was deployed. We computed $r$ using four seismic sensors (ABS2-ABS5). To check detection capacity, we tested source locations of the September and October explosions using both five and four sensors. The derived source locations using both station sets are the same with little difference in $r$ values.

\section{Seismic tremor source location}

The eruption sequence seismic observations at Ambae are enigmatic in the sense that there is very little local volcano tectonic (VT), long-period (LP; 0.5-10 Hz), and verylong-period (VLP; $<0.1 \mathrm{~Hz}$ ) earthquake activity. For the observation period, we detected only $<10$ VTs by a STA/ LTA (short-term average/long-term average; Trnkoczy 2009) detection algorithm. To identify subsurface LP and VLP activity indicating volcanic fluid movement beneath the Lake Voui, we applied both the STA/LTA and a waveform semblance method (e.g., Kawakatsu et al. 2000; Jolly et al. 2018; Park et al. 2020) to the continuous seismic data, but no significant events (semblance $<0.2$ ) were detected.

Instead, the primary seismic observations were expressed as tremor in semi-continuous or short duration bursts. The dearth of discrete seismic events hinders our efforts to understand the subsurface processes that might 
have operated during the deployment. Nevertheless, we are specifically interested in the application of methods that can point to subsurface magma residence and storage prior to eruption because these may offer opportunities to understand magma propagation properties that may ultimately be useful for hazards forecasting. Because we are limited to the tremor signal amplitude, we here explored the application of the amplitude source location (ASL) technique (e.g., Jolly et al. 2002; Battaglia and Aki 2003; Kumagai et al. 2009, 2011 and 2013; Tárraga et al. 2014; Ogiso and Yomogida 2015, Ichihara and Matsumoto 2017). ASL is increasingly popular as a means of locating emergent onset seismic activity. The approach utilises the amplitude decay as distance increases and it is appropriate to apply with tremor data having no clear $\mathrm{P}$ - or S-wave phases. However, a dense seismic network is needed to minimise location errors. Alternatively, Taisne et al. (2011) proposed a simple ratio method using the seismic intensities (amplitudes) recorded at a sensor pair to easily catch interesting information from near real-time data. Similar methods using RMS amplitude at Mount Spurr (McNutt et al. 1995) and amplitude computed from the power spectral density at Shinmoe-dake (Ichihara and Matsumoto 2017) were used to estimate tremor source locations.

We followed the amplitude ratio approach suggested by Taisne et al. (2011) to estimate tremor source locations. The seismic amplitude ratio is estimated as follows:

$\left.\frac{I_{i}}{I_{j}}\right|^{t}=\left(\frac{d_{j}^{t}}{d_{i}^{t}}\right)^{n} e^{-B\left(d_{i}^{t}-d_{j}^{t}\right)}$

with

$B=\frac{\pi f}{Q \beta}$

where $I_{i}$ and $I_{j}$ are the seismic amplitudes at a sensor pair of $i$ and $j$ located at distances $d_{i}$ and $d_{j}$ from the source, respectively. The index $n$ is determined by either surface wave $(n=0.5)$ or body wave $(n=1)$ assumption, and $\mathrm{B}$ is denoted as a function of frequency $f$, quality factor $Q$, and shear wave velocity $\beta$.

For our analysis, we used the input data of $5-10 \mathrm{~Hz}(f$ $=7.5 \mathrm{~Hz}$ ). This band is recommended to assume isotropic source radiation (Takemura et al. 2009; Kumagai et al. 2010). As part of pre-processing, we normalised the seismic data using coda wave of regional earthquakes following the same method as Ogiso and Yomogida (2015) to reduce site effects (Phillips and Aki 1986). We then performed two procedures suggested by Taisne et al. (2011): (1) calculate envelope and (2) reduce the sampling rate. The envelope was determined as a norm between Hilbert transform and filtered waveform and resampled as the median value of 10 -s window to exclude transient events. To eliminate tectonic earthquakes, Taisne et al. (2011) applied a median filter using a 5-min sliding window, but here we applied a 1-min window filter to avoid diminishing explosive signals. The amplitude ratios $I_{i}^{1 \min } / I_{j}^{1 \mathrm{~min}}$ used in this study were computed using a pair of stations ABS3/ABS4 $\left(I_{A B S 3}^{1 \text { min }} / I_{A B S 4}^{1 \min }\right)$ over the observation period. We also computed additional pairs of stations (Fig. S4), and variations in the ratios of multiple station pairs mostly show similar trends to $I_{A B S 3}^{1 \min } / I_{A B S 4}^{1 \min }$. Their discrepancy might indicate lateral source migration, but in this study, we will not deal with this in detail due to limited coverage of station configuration which may lead to biased results. Note that we only considered the time periods when the amplitudes of both $\mathrm{ABS} 3$ and $\mathrm{ABS} 4$ were three times stronger than noise level $(0.32$ and $0.41 \mu \mathrm{m} / \mathrm{s})$ in the $0.5-10 \mathrm{~Hz}$ band and the amplitude at ABS3 was two times stronger than noise level $(0.04 \mu \mathrm{m} / \mathrm{s})$ within the $5-10 \mathrm{~Hz}$ passband. These noise levels were determined from the quietest period in November 2018 after the October 30 explosion. These filters highlight only interesting high amplitude tremor and exclude periods when local volcanic activity was not present. In a detailed analysis of the ratios, we found that some volcanic tremor was recorded as weak signals at ABS4 and contaminated by local noise at the same time yielding incoherence compared to other stations. This implies that high-frequency signals of volcanic tremor were attenuated through propagation. We thus excluded signals having low RMS amplitude ratios computed within low $(0.5-5 \mathrm{~Hz})$ and high $(5-10 \mathrm{~Hz})$ frequency bands to eliminate high frequency noise.

\section{Results}

\section{Ground-coupled airwaves}

We applied the RTM approach to the seismic signals of the VLP passband for checking propagation velocity. Results indicate that the explosions dominantly propagated with low velocity $(335-365 \mathrm{~m} / \mathrm{s})$ implying sound wave velocity and therefore propagation through the atmosphere. These ground-coupled airwaves may also be observed within vertical displacement data (Yamada et al. 2016; Matoza et al. 2019b). To first order, positive pressure induces a downward displacement, and vice versa (Matoza et al. 2019b). Therefore, the polarity reversed displacements in the VLP band appear nearly identical to the propagated air-pressure variations. One example, from 1 September 2018, is shown in Fig. 5. Our observations clearly support that the apparent seismic VLP signals related to acoustic explosion signals at the Ambae summit vent region. 


\section{Detection of volcanic explosions}

The RTM detection results show many of additional acoustic bursts having high $r$ in the period August to October 2018 and in January 2019 (Fig. 6d). Interestingly, the coefficient trend remarkably decreased after the last reported explosion on 30 October 2018, and a strong $r$ of 0.98 was detected on 5 January 2019. The 2019 acoustic burst may affect the subsequent gas-steam emissions although we have no information about the onset and duration of the emitting activity. In the results, we interpreted acoustic bursts that have high correlation $(r \geq 0.8)$ as volcanic explosions. The choice for the threshold is arbitrary and based on a tradeoff between collection of a reasonably full set of possible eruptions and high probability of a near-vent emission based on high coherence. We also manually identified more than 400 acoustic bursts, which include impulse and complicated waves, on the basis of the triggered results. Most acoustic bursts ( 70\%) occurred in October before the last explosion (Figs. 6d and 6e), and their amplitudes were relatively low $(\sim 0.5 \mathrm{~Pa})$. The $r$ or infrasound signal detectability could be affected by strong wind noise level (e.g., Fee and Garces 2007; Matoza et al. 2009 and 2011; Castano et al. 2020; Sanderson et al. 2021). For example, low $r$ values occurred in late September and early November when strong RIAM trends were observed (Fig. 6d). In addition, diurnal amplitude variations were observed at all arrays (Fig. 4c) which may cause detection failure during daytime hours. However, the triggered events $(r \geq 0.8)$ look nearly identical to those observed at the time of strong tremor activity, and this implies that the detection results are related to volcanic activity.

The RTM approach using the ground coupled airwaves detected the reported explosions but also had numerous triggers during periods with no or weak volcanic tremor. For early observation periods with strong background tremor, only the largest explosion on 26 July was detected with a source location at the vent, and no additional explosions were detected for 16-24 July 2018. The results are inconsistent with the Wellington VAAC advisories and RSAM data which show vigorous volcanic activity in July 2018. We thus conclude that air-to-ground-coupled waves were inconsistently produced and/or recorded at Ambae in the given station configuration and strong seismic tremor activity and variable atmospheric conditions probably obscure the airwaves.

\section{Detection of subsurface processes}

Variations in the seismic amplitude ratios may reflect changes in source locations. Optimal source positions are determined at a minimum residual error between the observed and theoretical ratios using all available station pairs. In our case, however, a lack of station pairs including close stations can lead to an increase in location errors. We also have insufficient restriction of seismic velocity and attenuation models to calculate theoretical ratios. Thus, we are limited to an interpretation of the ratios as possibly related to the relative location between the two stations. In this case, the location may change in two possible ways: a change in source depth, with deeper source positions relating to lower ratio values, or a lateral shift in the source position. It is important to state that the characteristic frequency contents used in this analysis $(>5 \mathrm{~Hz})$ appear to preclude source inhomogeneity as a viable mechanism (Takemura et al. 2009; Kumagai et al. 2010). In order to adhere to a conservative interpretation of the ratios, we only interpret relative depth changes associated with variations in the observed ratios and acknowledge the possible impact of lateral tremor source migration. Our approach is justified based on observational reports that the vent area changed little throughout the eruptive episode. We also assume that seismic waves propagate with a steady velocity through the homogeneous subsurface affected by a constant attenuation so that ratio variations fundamentally represent relative depth changes.

To explain tremor activity effectively, we separated Ambae volcanic tremor into two groups (T1 and T2) depending on acoustic data availability and a relation to explosions. Tremor in $\mathrm{T} 1$ coincides with volcanic explosions (confirmed by coherent acoustic bursts; $r \geq 0.8$ in Fig. 6d), while T2 consists of pre- and inter-eruption tremor. Note that we only considered volcanic tremor which is likely to occur at Ambae. We excluded external sources such as the swarm activity near Ambrym in December 2018 and the early observation period when only seismic sensors operated. To display similarity of clear variations in the ratios, Fig. 7 shows the amplitude ratios (ABS3/ABS4) as a function of the amplitude of ABS3.

We note that eruptive tremor (T1) shows two different trends of the ratio variations (Fig. 7a): (1) fluctuating (low-high-low) ratios with a broad range of amplitudes (red dots in Fig. 7c) and (2) ratio clusters with a relatively narrow range of amplitudes (green dots in Fig. 7b). In the former group, the ratios widely vary between 2 and 12, and the amplitudes also reach $\sim 1.5 \mu \mathrm{m} / \mathrm{s}$. During distinct explosive activity, the ratios increased prior to the onset of explosions, and then explosions occurred with high ratio tremor followed by a return to the low ratios. If we assume that the ratios relate to depth changes, tremor sources ascended to near the vent and descended following explosions. The similar source migration (upward and downward) was also observed in other volcanoes, Tungurahua (Kumagai et al. 2011) and Shinmoe-dake (Ichihara and Matsumoto 
Fig. 7 Variations in the seismic amplitude ratios (implying relative source depths) of eruptive tremor (T1; $r \geq 0.8)$. a The amplitude ratios (unitless; dots) between ABS3 and ABS4 are displayed as a function of seismic amplitude $(\mu \mathrm{m} / \mathrm{s})$ recorded at ABS3 at the $5-10 \mathrm{~Hz}$ band. A relative depth variation beneath the active vent system is denoted as thick downward arrows implying greater tremor source depth. The ratios show two different trends (b, green; and $\mathrm{c}$, red), and detailed information is described in the "Detection of subsurface processes" section. d A theoretical ratio curve depending on depths beneath the vent using velocity $(\beta)$ of $3.4 \mathrm{~km} / \mathrm{s}$ and quality factor $(\mathrm{Q})$ of 35 . The eruptive tremor is likely to be generated at between the surface and $15 \mathrm{~km}$ beneath the vent

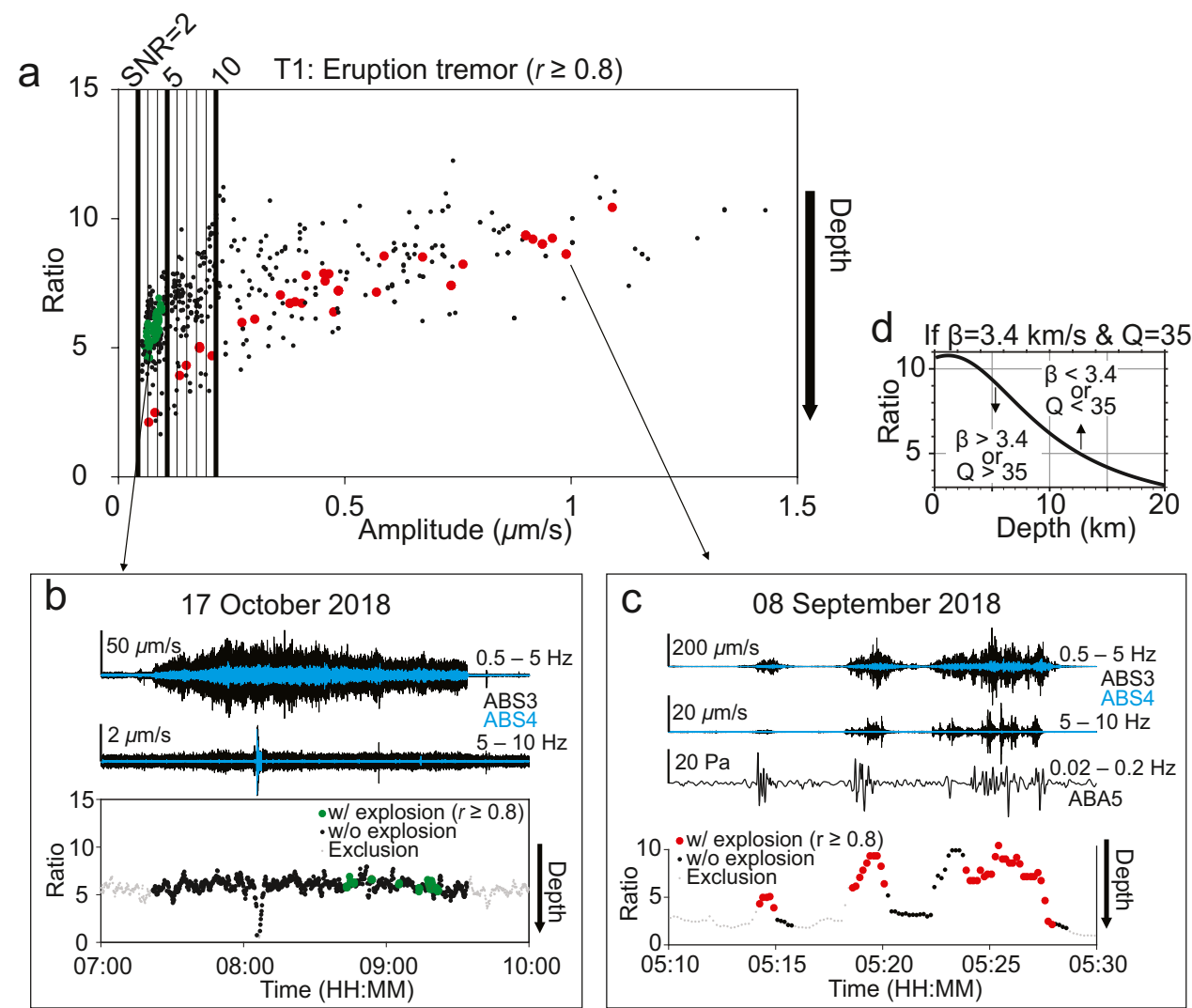

2017). The five reported ash advisories and at least four additional detected high-pressure explosions belong to this type. The duration of these distinct tremor episodes is less than $5 \mathrm{~min}$; hence, the source depths rapidly change during the explosions. The latter one is mainly observed with low pressure $(<1 \mathrm{~Pa})$ and continuous low SNR tremor $(<5)$, and the ratio changes are relatively consistent between 4

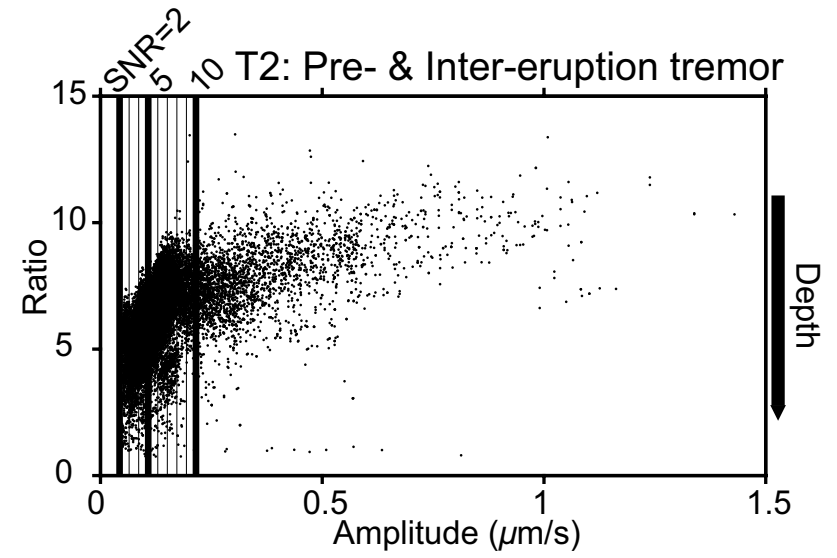

Fig. 8 Amplitude ratio variations for pre- and inter-eruptive tremor (T2). The ratios were computed using ABS3 and ABS4 at the 5-10 Hz band and 7. These tremor excitations are interpreted as a deeper source excitation rather than near surface, but it is uncertain because the amplitudes significantly diminished at both stations after frequency filtering $(5-10 \mathrm{~Hz})$.

Aside from these episodes, low infrasound pressure bursts do not always simultaneously occur with tremor activity. In some cases, relatively shallow tremor occurred ahead of the infrasound bursts. However, it is ambiguous how the tremor activity directly or indirectly plays a role as a cause of explosions due to inconsistent occurrence. The preceding tremor belongs to T2 which consists of volcanic tremor without simultaneous explosive activity (Fig. 8). T2 also includes intermittent tremor between explosions. We thus address $\mathrm{T} 2$ as pre- and inter-eruption tremor. Unlike $\mathrm{T} 1, \mathrm{~T} 2$ has both short and long duration tremor. Long-duration tremor show irregularly fluctuating ratios (and inferred depths) while the tremor progressed. Conversely, short-duration tremor was sometimes similar to the first trend of $\mathrm{T} 1$. The ratios and corresponding relative depths for explosive and non-eruptive tremor cannot be distinguished in a robust statistical way, but large eruptive tremor show the consistent fluctuating variations in the ratios with acoustic activity of high pressure (Fig. 7). Therefore, the changes in the ratios and relative depths are likely to be used to quickly recognise volcanic unrest. 


\section{Discussion}

As infrasound signals weakly attenuate in the atmosphere, they allow for eruptive activity to be detected by local and remote arrays (e.g., Matoza et al. 2007, 2019a; Fee et al. 2011; Fee and Matoza 2013). Owing to weak attenuation at local distances, we observe coherent infrasound waves at the given acoustic arrays during the Ambae eruptions. Moreover, low-frequency content in the eruptive infrasound signals is dominant, which leads to successful detection of "unreported" explosions through the aforementioned RTM method. Determining acoustic source locations requires careful interpretation because the RTM results often point to different source positions rather than the vent due to cycle skipping of waveform cross-correlation coefficient, and these are observed along with ENE-WSW because of the sensor array response (see other examples producing high correlation coefficients in Fig. 6a). At Ambae, the acoustic source appears to propagate from a single position consistent with the vent, providing confidence that we can detect such events using the acoustic data.

Interestingly, Ambae eruptive infrasound signals mostly consist of a train of multiple pulses (Fig. 3). At Aso volcano, Yamada et al. (2017) observed similar pulse trains of infrasound VLP signals and confirmed that these are associated with the emergence of new ash emissions using video images. Although we have no comparable visual observations, our observed waveforms at Ambae are likely to result from a similar sequence of multiple explosions. The low-frequency (VLP) nature of the multiple pulses is also noteworthy. Such VLP infrasound associated with explosion mechanisms while not unprecedented is not typical. Low-frequency content could be attributed to a submerged vent, with water acting as a low-pass filter (Fee et al. 2020). The active vent at Ambae is centred on Lake Voui, and lake water may be involved in the explosion and acoustic source mechanism. However, we can only infer lake water-magma interaction from eruption style (phreatomagmatic) due to inadequate visual observation. We note that ash collected from under the depositing plume was very fine, characteristic of phreatomagmatic eruptions (Kilgour et al. in prep.) and thus indicating lake water involvement.

Volcanic tremor was examined using the seismic amplitude ratios recorded at the close (ABS3; 8.5 km) and far (ABS4; 17.4 km) field stations. The lack of available close stations ( $<$ a few kilometres) to the vent may lead to a loss of detection capability for the smallest explosions, which may in turn lead to biased source positions. We thus restricted the subsurface location analysis by relative depth beneath the vent. The analysis shows that shallow tremor activity at Ambae mostly coincides with the large explosions based on the coherent high amplitude acoustic bursts, and the depths then descend as the eruptions progress. The absence of close stations also leads to a possible reason of non-detection of subsurface LP and VLP beneath the vent area which may be influenced by eruption. If Ambae produced subsurface LP and VLP signals, the amplitude (magnitude) would be insufficiently low to detect at the given network. Thus, we cannot confirm low-level seismic activity for this eruption sequence.

The detected explosions did not always occur with shallow tremor. For example, the explosive activity in October 2018 was detected by small acoustic signals (mean zero-topeak of $\sim 0.5 \mathrm{~Pa}$ ) and the corresponding seismic signals may be too weak to detect above the noise level at the given stations (> $8.5 \mathrm{~km}$ ). Ripepe et al. (2001) also observed that high amplitude seismic signals related to small acoustic impulses diminished with increased distance at Mt. Etna in 1998. On the other hand, one plausible mechanism is that tremors continuously occurred prior to the explosive infrasound events and hence could directly or indirectly contribute to triggering within the near surface volcanic system. Another feasible assumption is gas coalescence in magma followed by bubble bursting (Ripepe and Gordeev 1999; Girona et al. 2019). Although these are unidentified from our analysis, it might be a worthwhile further study on gas/magma modelling at Ambae.

Ambae volcanic system has been rarely studied. A recent petrological study of the 2017-2018 eruptive scoria suggested that Ambae hosts a shallow magma reservoir between 0.5 and $3 \mathrm{~km}$ (relative to the summit), where magma likely stalled prior to eventual eruption (Moussallam et al. 2019). Furthermore, they suggested that the origin of erupted magma is $\sim 14 \mathrm{~km}$. In our case, explosive tremor mostly have the ratios of $>4$ implying that the tremor is generated at between the surface and $15 \mathrm{~km}$ beneath the vent assuming the velocity $\beta$ of $3.4 \mathrm{~km} / \mathrm{s}$ and quality factor $Q$ of 35 (Fig. 7d). The velocity referred to Prevot et al. (1991) as an average velocity and the quality factor was determined from a synthetic test with the reported explosions. Although we have analysed relative depth variations because neither parameter is constrained, the source depth from the theoretical ratio and comparable observed ratios well overlaps with magma origin from other paper (Moussallam et al. 2019). However, it is difficult to recognise more detailed spatial geometry of the magmatic system at Ambae because discrete locatable seismicity did not occur, and the limited network geometry could not resolve horizontal variations in seismic tremor.

The implied depth range for source migrations must also be tested against plausible source migration processes. If the tremor source indeed migrated several kilometres over an observation period of a few minutes (Fig. 7), a plausible mechanism must be found. Plausible mass advection times have been modelled for the ascent of fluids from depth 
towards the surface (Jolly et al. 2018). However, such analyses were done for gases in hydrothermal systems, not for magmatic conditions likely at Ambae, and it seems unlikely that a downward post-eruption advection would occur at the suggested rates. Alternatively, the propagation of a pressure front through the fluid filled conduit is plausible. In this case, the downward migration of a depressurisation front or bubble growth might be evoked (Kumagai et al. 2011). However, it is uncertain what mechanism might produce a broad-spectrum migrating source within an established vent system. A third possible mechanism could relate to the existence of two superimposed source locations, one at the eruptive vent, and a second at depth. The deeper source might be more persistent but excited at lower amplitudes, while the vent source may only be excited during eruptive activity, then the superposition of the two source processes might produce an apparent and rapid change in the ratios. A variation on this concept might relate to a linear excitation of an extended vent structure. In this case, the entire vent structure may be excited for an extended duration, but the shallow vent area is energetically dominant during the active eruptive episode. We regard this mechanism as plausible but unconfirmed by the data.

As an alternative to a source migration mechanism discussed above, we might consider some alternative processes. For example, the seismic amplitude ratios are probably affected by other factors such as changes in velocity and attenuation. Although we assumed the steady and isotropic elastic medium in this study, temporal changes caused by pressure variations have been commonly observed at active volcanoes associated with eruptions (Fehler et al. 1988; Ratdomopurbo and Poupinet 1995; Brenguier et al. 2008; Duputel et al. 2009; Caudron et al. 2019) and may yield additional uncertainty in our interpretation. As aforementioned, frequency-dependent attenuation is also a possible impact factor on the ratios. Thus, the amplitude ratios related to large eruptions may fundamentally reflect an effect of source depth changes; otherwise, low amplitude tremor can be significantly influenced by attenuation at the given seismic network. Future study should consider these effects.

\section{Conclusions}

We have investigated seismo-acoustic activity excited from both surface and subsurface processes at Ambae. The temporary local network dominantly recorded seismic tremor and low-frequency infrasound signals for the eruptive period. The complimentary data sets have generally contrasting frequency contents that indicate their different processes. Based on the seismo-acoustic features, we suggest three key observations in this study:
1) Ground-coupled airwaves are observed as seismic VLP signals during large explosions at Ambae, and the apparent VLP are unrelated to subsurface volcanic fluid processes.

2) Explosions can be detected using coherent infrasound signals, and more than 400 small and large events were observed at Ambae between August 2018 and January 2019.

3) The amplitude ratio computed using a pair of seismic data increased at the onset of large explosions and then decreased. It can be interpreted as the seismic source ascent and descent between the surface and $15 \mathrm{~km}$ depth beneath the active vent.

Many volcano regions globally still have insufficient visual surveillance and lack close station seismic deployments. To overcome this drawback at Ambae, we integrated seismoacoustic observations and successfully detected unknown volcanic explosions associated with shallow tremor activity. As has been found in numerous other case studies (e.g., Petersen and McNutt 2007; Jolly et al. 2014; Lyons et al. 2010; Matoza et al. 2007 and 2019b), the combined analyses of seismo-acoustic data are worthwhile to apply to an early stage of monitoring for volcanic activity and to quickly determine eruptive events.

Supplementary Information The online version contains supplementary material available at https://doi.org/10.1007/s00445-021-01474-z.

Acknowledgements We acknowledge GNS Science and Vanuatu Meteorology and Geohazards Department for collecting the data used in this study. We also thank Peter Kreft from New Zealand MetService for supplying detailed wind and ash information. Janvon Cevuard, Athanas Worwor, and Julius Mala supported the monitoring and the field campaign in Port Vila and Ambae, Vanuatu. We thank Associate Editor Andrea Cannata and two anonymous reviewers for their constructive comments that improved the manuscript.

Funding (AJ, GK, RJ, and BK (through subcontract)) Hazard and Risk Management Program from the New Zealand Strategic Science Investment Fund (SSIF) allocated by the New Zealand Ministry of Business, Innovation \& Employment (MBIE). R.S.M. was supported by NSF grants EAR-1620576 and EAR-1847736.

\section{Declarations}

Conflict of interest The authors declare no competing interests.

Open Access This article is licensed under a Creative Commons Attribution 4.0 International License, which permits use, sharing, adaptation, distribution and reproduction in any medium or format, as long as you give appropriate credit to the original author(s) and the source, provide a link to the Creative Commons licence, and indicate if changes were made. The images or other third party material in this article are included in the article's Creative Commons licence, unless indicated otherwise in a credit line to the material. If material is not included in the article's Creative Commons licence and your intended use is not permitted by statutory regulation or exceeds the permitted use, you will need to obtain permission directly from the copyright holder. To view a copy of this licence, visit http://creativecommons.org/licenses/by/4.0/. 


\section{References}

Aki K, Fehler M, Das S (1977) Source mechanism of volcanic tremor: fluid-driven crack models and their application to the 1963 Kilauea eruption. J Volcanol Geotherm Res 2:259-287. https:// doi.org/10.1016/0377-0273(77)90003-8

Alparone S, Andronico D, Lodato L, Sgroi T (2003) Relationship between tremor and volcanic activity during the Southeast Crater eruption on Mount Etna in early 2000. J Geophys Res: Solid Earth 108:B5. https://doi.org/10.1029/2002JB001866

Alparone S, Cannata A, Gresta S (2007) Time variations of spectral and wavefield features of volcanic tremor at Mt. Etna (January-June 1999). J Volcanol Geotherm Res 161:318-332. https://doi.org/10. 1016/j.jvolgeores.2006.12.012

Bani P, Oppenheimer C, Varekamp JC, Quinou T, Lardy M, Carn S (2009) Remarkable geochemical changes and degassing at Voui crater lake, Ambae volcano, Vanuatu. J Volcanol Geotherm Res 188:347-357. https://doi.org/10.1016/j.jvolgeores.2009.09.018

Battaglia J, Aki K (2003) Location of seismic events and eruptive fissures on the Piton de la Fournaise volcano using seismic amplitude. J Geophys Res: Solid Earth 108:B8. https://doi.org/10.1029/ 2002JB002193

Battaglia J, Aki K, Ferrazzini V (2005) Location of tremor source and estimation of lava output using tremor source amplitude on the Piton de la Fournaise volcano: 1. Location of tremor sources. J Volcanol Geotherm Res 147:268-290. https://doi.org/10.1016/j. jvolgeores.2005.04.005

Blom P, Iezzi A, Euler G (2020) Seismoacoustic analysis of underground explosions using the Rayleigh integral. Geophys J Int 223:1069-1085. https://doi.org/10.1093/gji/ggaa363

Brenguier F, Shapiro NM, Campillo M, Ferrazzini V, Duputel Z, Coutant O, Nercessian A (2008) Towards forecasting volcanic eruptions using seismic noise. Nat Geosci 1:126-130. https:// doi.org/10.1038/ngeo104

Caudron C, Girona T, Taisne B, Suparjan GH, Kristianto K (2019) Change in seismic attenuation as a long-term precursor of gasdriven eruptions. Geology 47:632-636. https://doi.org/10.1130/ G46107.1

Chardot L, Jolly AD, Kennedy BM, Fournier N, Sherburn S (2015) Using volcanic tremor for eruption forecasting at White Island volcano (Whakaari), New Zealand. J Volcanol Geotherm Res 302:11-23. https://doi.org/10.1016/j.jvolgeores.2015.06.001

De Angelis S, Fee D, Haney M, Schneider D (2012) Detecting hidden volcanic explosions form Mt. Cleveland Volcano, Alaska with infrasound and ground-coupled airwaves. Geophys Res Lett 39:L21312. https://doi.org/10.1029/2012GL053635

Duputel Z, Ferrazzini V, Brenguier F, Shapiro N, Campillo M, Nercessian A (2009) Real time monitoring of relative velocity changes using ambient seismic noise at the Piton de la Fournaise volcano (La Réunion) from January 2006 to June 2007. J Volcanol Geotherm Res 184:164-173. https://doi.org/10.1016/j. jvolgeores.2008.11.024

Endo ET, Murray T (1991) Real-time Seismic Amplitude Measurement (RSAM): a volcano monitoring and prediction tool. Bull Volcanol 53:533-545. https://doi.org/10.1007/BF00298154

Fee D, Garces M (2007) Infrasonic tremor in the diffraction zone. Geophys Res Lett 34:L16826. https://doi.org/10.1029/2007G L030616

Fee D, McNutt SR, Lopez T, Arnoult K, Szuberla CAL, Olson JV (2011) Combining local and remote infrasound recordings from the 2009 Redoubt Volcano eruption. J Volcanol Geotherm Res 259:100-114. https://doi.org/10.1016/j.jvolgeores.2011.09.012

Fee D, Matoza RS (2013) An overview of volcano infrasound: from hawaiian to plinian, local to global. J Volcanol Geotherm Res 249:123-139. https://doi.org/10.1016/j.jvolgeores.2012.09.002
Fee D, Haney M, Matoza R, Szuberla C, Lyons J, Waythomas C (2016) Seismic envelope-based detection and location of ground-coupled airwaves from volcanoes in Alaska. Bull Seismol Soc Am 106:1024-1035. https://doi.org/10.1785/0120150244

Fee D, Haney MM, Matoza RS, Van Easton AR, Cervelli P, Schneider DJ, Iezzi AN (2017) Volcanic tremor and plume height hysteresis from Pavlof volcano, Alaska. Science 355:45-48. https://doi.org/ 10.1126/science.aah6108

Fee D, Lyons J, Haney M, Wech A, Waythomas C, Diefenbach AK, Lopez T, Van Eaton A, Schneider D (2020) Seismo-acoustic evidence for vent drying during shallow submarine eruptions at Bogoslof volcano. Alaska Bull Volcanol 82:2. https://doi.org/10. 1007/s00445-019-1326-5

Fee D, Toney L, Kim K, Sanderson RW, Iezzi AM, Matoza RS, De Angelis S, Jolly AD, Lyons JJ, Haney MM (2021) Local explosion detection and infrasound localization by reverse time migration using 3-D finite difference wave propagation. Front Earth Sci 9:44. https://doi.org/10.3389/feart.2021.620813

Fehler M, Roberts P, Fairbanks T (1988) A temporal change in coda wave attenuation observed during an eruption of Mount St. Helens J Geophys Res: Solid Earth 93:4367-4373. https://doi.org/10. 1029/JB093iB05p04367

Ferrick MG, Qamar A, St. Lawrence WF (1982) Source mechanism of volcanic tremor. J Geophys Res: Solid Earth 87:8675-8683. https://doi.org/10.1029/JB087iB10p08675

Girona T, Caudron C, Huber C (2019) Origin of shallow volcanic tremor: the dynamics of gas pockets trapped beneath thin permeable media. J Geophys Res: Solid Earth 124:4831-4861. https:// doi.org/10.1029/2019JB017482

Global Volcanism Program (1995) Report on Ambae (Vanuatu) (Wunderman, R., ed.) Bulletin of the Global Volcanism Network, 20:8. Smithsonian Institution. https://doi.org/10.5479/si.GVP.BGVN1 99508-257030

Global Volcanism Program (2013) Report on Ambae (Vanuatu) (Wunderman, R., ed.) Bulletin of the Global Volcanism Network, 38:5. Smithsonian Institution. https://doi.org/10.5479/si.GVP.BGVN2 01305-257030

Global Volcanism Program (2018) Report on Ambae (Vanuatu) (Crafford, A.E., and Venzke, E., eds.) Bulletin of the Global Volcanism Network, 43:2. Smithsonian Institution. https://doi.org/10.5479/ si.GVP.BGVN201802-257030

Global Volcanism Program (2019) Report on Ambae (Vanuatu) (Krippner, J.B., and Venzke, E., eds.) Bulletin of the Global Volcanism Network, 44:2. Smithsonian Institution. https://doi.org/10.5479/ si.GVP.BGVN201902-257030

Hagerty MT, Schwartz SY, Garcés MA, Protti M (2000) Analysis of seismic and acoustic observations at Arenal Volcano, Costa Rica, 1995-1997. J Volcanol Geotherm Res 101:27-65. https://doi.org/ 10.1016/S0377-0273(00)00162-1

Haney MM, Fee D, McKee KF, Lyons JJ, Matoza RS, Wech AG, Tepp G, Searcy C, Mikesell TD (2020) Co-eruptive tremor from Bogoslof volcano: seismic wavefield composition at regional distance. Bull Volcanol 82:18. https://doi.org/10.1007/ s00445-019-1347-0

Ichihara M, Takeo M, Yokoo A, Oikawa J, Ohminato T (2012) Monitoring volcanic activity using correlation patterns between infrasound and ground motion. Geophys Res Lett 39:L04304. https:// doi.org/10.1029/2011GL050542

Ichihara M (2016) Seismic and infrasonic eruption tremors and their relation to magma discharge rate: a case study for sub-Plinian events in the 2011 eruption of Shinmoe-dake, Japan. J Geophys Res: Solid Earth 1217101-71118. https://doi.org/10.1002/2016J B013246

Ichihara M, Matsumoto S (2017) Relative source locations of continuous tremor before and after the subplinian events at Shinmoe-dake, 
in 2011. Geophys Res Lett 44:10871-10877. https://doi.org/10. 1002/2017GL075293

Ishii K, Yokoo A, Kagiyama T, Ohkura T, Yoshikawa S, Inoue H (2019) Gas flow dynamics in the conduit of Strombolian explosions inferred from seismo-acoustic observations at Aso volcano. Japan Earth Planets Space 71:13. https://doi.org/10.1186/ s40623-019-0992-z

Ishii M, Shearer PM, Houston H, Vidale JE (2005) Extent, duration and speed of the 2004 Sumatra-Andaman earthquake imaged by the Hi-Net array. Nature 435:933-936. https://doi.org/10.1038/ nature 03675

Johnson JB, Aster RC (2005) Relative partitioning of acoustic and seismic energy during Strombolian eruptions. Vanuatu J Volcanol Geotherm Res 148:334-354. https://doi.org/10.1016/j.jvolgeores. 2005.05.002

Johnson JB, Malone SD (2007) Ground-coupled acoustic airwaves from Mount St. Helens provide constraints on the May 18, 1980 eruption. Earth Planet Sci Lett 258:16-31. https://doi.org/10. 1016/j.eps1.2007.03.001

Jolly AD, Thompson G, Norton GE (2002) Locating pyroclastic flows on Soufriere Hills Volcano, Montserrat, West Indies, using amplitude signals from high dynamic range instruments. J Volcanol Geotherm Res 118:299-317. https://doi.org/10.1016/S03770273(02)00299-8

Jolly AD, Sherburn S, Jousset P, Kilgour G (2010) Eruption source processes derived from seismic and acoustic observations of the 25 September 2007 Ruapehu eruption-North Island, New Zealand. J Volcanol Geotherm Res 191:33-45. https://doi.org/10.1016/j. jvolgeores.2010.01.009

Jolly AD, Jousset P, Lyons JJ, Carniel R, Fournier N, Fry B, Miller C (2014) Seismo-acoustic evidence for an avalanche driven phreatic eruption through a beheaded hydrothermal system: an example from the 2012 Tongariro eruption. J Volcanol Geotherm Res 286:331-347. https://doi.org/10.1016/j.jvolgeores. 2014.04.007

Jolly A, Lokmer I, Christenson B, Thun J (2018) Relating gas ascent to eruption triggering for the April 27, 2016, White Island (Whakaari), New Zealand eruption sequence. Earth Planets Space 70:1777. https://doi.org/10.1186/s40623-018-0948-8

Julian BR (1994) Volcanic tremor: nonlinear excitation by fluid flow. J Geophys Res: Solid Earth 99:11859-11877. https://doi.org/10. 1029/93JB03129

Kawakatsu H, Kaneshima S, Matsubayashi H, Ohminato T, Sudo Y, Tsutsui T, Uhira K, Yamasato H, Ito H, Legrand D (2000) Aso94: Aso seismic observation with broadband instruments. J Volcanol Geotherm Res 101:129-154. https://doi.org/10.1016/S03770273(00)00166-9

Kiser E, Ishii M (2011) The 2010 Mw 8.8 Chile earthquake: triggering on multiple segments and frequency-dependent rupture behavior. Geophys Res Lett 38:L07301. https://doi.org/10.1029/2011G L047140

Konstantinou KI, Schlindwein V (2002) Nature, wavefield properties and source mechanism of volcanic tremor: a review. J Volcanol Geotherm Res 119:161-187. https://doi.org/10.1016/S03770273(02)00311-6

Kumagai H, Palacios P, Maeda T, Castillo DB, Nakano M (2009) Seismic tracking of lahars using tremor signals. J Volcanol Geotherm Res 183:112-121. https://doi.org/10.1016/j.jvolgeores.2009.03. 010

Kumagai H, Nakano M, Maeda T, Yepes H, Palacios P, Ruiz M, Arrais S, Vaca M, Molina I, Yamashima T (2010) Broadband seismic monitoring of active volcanoes using deterministic and stochastic approaches. J Geophys Res: Solid Earth 115:B08303. https://doi. org/10.1029/2009JB006889

Kumagai H, Placios P, Ruiz M, Yepes H, Kozono T (2011) Ascending seismic source during an explosive eruption at Tungurahua volcano. Ecuador Geophys Res Lett 38:L01306. https://doi.org/ 10.1029/2010GL045944

Kumagai H, Lacson R Jr, Maeda Y, Figueroa MS II, Yamashina T, Ruiz M, Palacios P, Ortiz H, Yepes H (2013) Source amplitudes of volcano-seismic signals determined by the amplitude source location method as a quantitative measure of event size. J Volcanol Geotherm Res 247:57-71. https://doi.org/10.1016/j.jvolg eores.2013.03.002

Kurokawa AK, Ichihara M (2020) Identification of infrasonic and seismic components of tremors in single-station records: application to the 2013 and 2018 events at Ioto Island. Japan Earth Planets Space 72:171. https://doi.org/10.1186/s40623-020-01302-2

Lyons JJ, Waite GP, Rose WI, Chigna G (2010) Patterns in open vent, strombolian behavior at Fuego volcano, Guatemala, 2005-2007. Bull Volcanol 72:1. https://doi.org/10.1007/s00445-009-0305-7

Lyons JJ, Haney MM, Werner C, Kelly P, Patrick M, Kern C, Trusdell $F$ (2016) Long period seismicity and very long period infrasound driven by shallow magmatic degassing at Mount Pagan, Mariana Islands. J Geophys Res: Solid Earth 121:188-209. https://doi.org/ 10.1002/2015JB012490

Lyons JJ, Haney MM, Fee D, Wech AG, Waythomas CF (2019) Infrasound from giant bubbles during explosive submarine eruptions. Nat Geosci 12:952-958. https://doi.org/10.1038/ s41561-019-0461-0

Marcillo O, Johnson JB, Hart D (2012) Implementation, characterization, and evaluation of an inexpensive low-power low-noise infrasound sensor based on a micromachined differential pressure transducer and a mechanical filter. J Atmos Oceanic Technol 29:1275-1284. https://doi.org/10.1175/JTECH-D-11-00101.1

Matoza RS, Hedlin MAH, Garces MA (2007) An infrasound array study of Mount St. Helens J Volcanol Geotherm Res 160:249262. https://doi.org/10.1016/j.jvolgeores.2006.10.006

Matoza RS, Garcés MA, Chouet BA, D'Auria L, Hedlin MAH, De Croot-Hedlin C, Waite GP (2009) The source of infrasound associated with long-period events at Mount St. Helens J Geophys Res: Solid Earth 114:B04305. https://doi.org/10.1029/2008J B006128

Matoza RS, Vergoz J, Le Pichon A, Ceranna L, Green DN, Evers LG, Ripepe M, Campus P, Liszka L, Kvaerna T, Kjartansson E, Hoskuldsson A (2011) Long-range acoustic observations of the Eyjafjallajökull eruption, Iceland, April-May 2010. Geophys Res Lett 38:L06308. https://doi.org/10.1029/2011GL047019

Matoza RS, Fee D, López TM (2014) Acoustic characterization of explosion complexity at Sakurajima, Karymsky, and Tungurahua volcanoes. Seismol Res Lett 85:1187-1199. https://doi.org/10. 1785/0220140110

Matoza RS, Fee D, Green DN, Le Pichon A, Vergoz J, Haney MM, Franco L, Valderrama OA, Kelley MR, McKee K, Ceranna L (2018) Local, regional, and remote seismo-acoustic observations of the April 2015 VEI 4 eruption of Calbuco volcano, Chile. J Geophys Res: Solid Earth 123:3814-3827. https://doi.org/10. 1002/2017JB015182

Matoza R, Fee D, Green D, Mialle P (2019a) Volcano infrasound and the International Monitoring System. In: Le Pichon A, Blanc E, Hauchecorne A (eds) Infrasound monitoring for atmospheric studies: Challenges in middle-atmosphere dynamics and societal benefits. Springer, Cham, pp 1023-1077. https://doi.org/10.1007/ 978-3-319-75140-5_33

Matoza RS, Arciniega-Ceballos A, Sanderson RW, Mendo-Pérez G, Rosado-Fuentes A, Chouet BA (2019b) High-broadband seismoacoustic signature of Vulanian explosions at Popocatépetl volcano, Mexico. Geophys Res Lett 46:148-157. https://doi.org/10.1029/ 2018GL080802

McKee K, Fee D, Haney M, Matoza RS, Lyons J (2018) Infrasound signal detection and back azimuth estimation using ground-coupled 
airwaves on a seismo-acoustic sensor pair. J Geophys Res: Solid Earth 123:6826-6844. https://doi.org/10.1029/2017JB015132

McNutt SR (1992) Volcanic tremor. In: Encyclopaedia of earth system science. Academic Press, San Diego, vol 4, pp 417-425

McNutt SR, Tytgat GC, Power JA (1995) Preliminary analysis of volcanic tremor associated with 1992 eruptions of Crater Peak, Mount Spurr Volcano, Alaska. US Geol Surv Bull 2139:161-178

Moran SC, Matoza RS, Garcés MA, Hedlin MAH, Bowers D, Scott WE, Sherrod DR, Vallance JW (2008) Seismic and acoustic recordings of an unusually large rockfall at Mount St. Helens, Washington. Geophys Res Lett 35:19. https://doi.org/10.1029/ 2008GL035176

Moussallam Y, Rose-Koga E, Koga KT, Médard E, Bani P, Devidal J-L, Tari D (2019) Fast ascent rate during the 2017-22018 Plinian eruption of Ambae (Aoba) volcano: a petrological investigation. Contrib Mineral Petrol 174:90. https://doi.org/10.1007/ s00410-019-1625-z

Nadeau PA, Palma JL, Waite GP (2011) Linking volcanic tremor, degassing, and eruption dynamics via $\mathrm{SO}_{2}$ imaging. Geophys Res Lett 38. https://doi.org/10.1029/2010GL045820

Németh K, Cronin SJ (2009) Phreatomagmatic volcanic hazards where rift-systems meet the sea, a study from Ambae Island, Vanuatu. J Volcanol Geotherm Res 180:246-258. https://doi.org/10.1016/j. jvolgeores.2008.08.011

Nishida K, Ichihara M (2016) Real-time infrasonic monitoring of the eruption at a remote island volcano using seismoacoustic cross correlation. Geophys J Int 204:748-752. https://doi.org/10.1093/ gji/ggv478

Ogiso M, Yomogida K (2015) Estimation of locations and migration of debris flows on Izu-Oshima Island, Japan, on 16 October 2013 by the distribution of high frequency seismic amplitudes. J Volcanol Geotherm Res 298:15-26. https://doi.org/10.1016/j.jvolg eores.2015.03.015

Parfitt EA (2004) A discussion of the mechanisms of explosive basaltic eruptions. J Volcanol Geotherm Res 134:77-107. https://doi.org/ 10.1016/j.jvolgeores.2004.01.002

Park I, Jolly A, Lokmer I, Kennedy B (2020) Classification of longterm very long period (VLP) earthquakes at Whakaari/White Island volcano. New Zealand Earth Planets Space 72:92. https:// doi.org/10.1186/s40623-020-01224-Z

Petersen T, McNutt SR (2007) Seismo-acoustic signals associated with degassing explosions recorded at Shishaldin Volcano, Alaska, 2003-2004. Bull Volcanol 69:527-536. https://doi.org/10.1007/ s00445-006-0088-z

Phillips WS, Aki K (1986) Site amplification of coda waves from local earthquakes in central California. Bull Seismol Soc Am 76:627-648

Prevot R, Roecker SW, Isacks BL, Chatelain JL (1991) Mapping of low $\mathrm{P}$ wave velocity structures in the subducting plate of the central New Hebrides, southwest Pacific. J Geophys Res: Solid Earth 96:19825-19842. https://doi.org/10.1029/91JB01837

Ratdomopurbo A, Poupinet G (1995) Monitoring a temporal change of seismic velocity in a volcano: Application to the 1992 eruption of Mt. Merapi (Indonesia). Geophys Res Lett 22:775-778. https:// doi.org/10.1029/95GL00302

Ripepe M, Gordeev E (1999) Gas bubble dynamics model for shallow volcanic tremor at Stromboli. J Geophys Res: Solid Earth 104:10639-10654. https://doi.org/10.1029/98JB02734

Ripepe M, Coltelli M, Privitera E, Gresta S, Moretti M, Piccinini D (2001) Seismic and infrasonic evidences for an impulsive source of the shallow volcanic tremor at Mt. Etna. Italy Geophys Res Lett 28:1071-1074. https://doi.org/10.1029/2000GL011391
Rouland D, Cisternas A, Denkmann R, Dufumier H, Régnier M, Lardy M (2001) The December 1994 seismic swarm near Aoba (AMBAE) volcano, Vanuatu, and its relationship with the volcanic processes. Tectonophysics 338:23-44. https://doi.org/10. 1016/S0040-1951(01)00074-9

Salerno GG, Burton M, Di Grazia G, Caltabiano T, Oppenheimer C (2018) Coupling between magmatic degassing and volcanic tremor in basaltic volcanism. Front Earth Sci 6:157. https://doi. org/10.3389/feart.2018.00157

Sanderson RW, Matoza RS, Fee D, Haney MM, Lyons JJ (2020) Remote detection and location of explosive volcanism in Alaska with the EartScope Transportable Array. J Geophys Res: Solid Earth 125. https://doi.org/10.1029/2019JB018347

Sanderson RW, Matoza RS, Haymon RM, Steidl JH (2021) A pilot experiment on infrasonic lahar detection at Mount Adams, Cascades: ambient infrasound and wind-noise characterization at quiescent stratovolcano. Seismol Res Lett. https://doi.org/10.1785/ 0220200361

Siebert L, Cottrell E, Venzke E, Andrews B (2015) Earth's volcanoes and their eruptions: an overview. In: Sigurdsson H (ed) The encyclopedia of volcanoes, 2 nd edn. Academic Press, Cambridge, pp 239-255

Siebert L, Simkin T, Kimberly P (2010) Volcanoes of the world. Univ of California Press

Smith CM, McNutt SR, Thompson G (2016) Ground-coupled airwaves at Pavlof Volcano, Alaska, and their potential for eruption monitoring. Bull Volcanol 78:52. https://doi.org/10.1007/ s00445-016-1045-0

Taisne B, Brenguier F, Shapiro NM, Ferrazzini V (2011) Imaging the dynamics of magma propagation using radiated seismic intensity. Geophys Res Lett 38. https://doi.org/10.1029/2010G L046068

Takemura S, Furumura T, Saito T (2009) Distortion of the apparent $\mathrm{S}$-wave radiation pattern in the high-frequency wavefield: Tottori-Ken Seibu, Japan, earthquake of 2000. Geophys J Int 178:950-961. https://doi.org/10.1111/j.1365-246X.2009. 04210.x

Tárraga M, Martí J, Abella R, Carniel R, López C (2014) Volcanic tremors: good indicators of change in plumbing systems during volcanic eruptions. J Volcanol Geotherm Res 273:33-40. https:// doi.org/10.1016/j.jvolgeores.2014.01.003

Trnkoczy A (2009) Understanding and parameter setting of sta/lta trigger algorithm, In New Manual of Seismological Observatory Practice (NMSOP) (pp. 1-20). Deutsches GeoForschungsZentrum GFZ

Walker KT, Shelby R, Hedlin MA, Groot-Hedlin C, Vernon F (2011) Western US infrasonic catalog: Illuminating infrasonic hot spots with the USArray. J Geophys Res: Solid Earth 116. https://doi. org/10.1029/2011JB008579

Warden AJ (1970) Evolution of Aoba caldera volcano. New Hebrides, Bulletin Volcanologique 24:107-140

Yamada T, Aoyama H, Nishimura T, Takiwara H, Nakamichi $H$, Oikawa J, Iguchi M, Hendrasto M, Suparman Y (2016) Initial phases of explosion earthquakes accompanying Vulcanian eruptions at Lokon-Empung volcano, Indonesia. J Volcanol Geotherm Res 327:310-321. https://doi.org/10.1016/j.jvolgeores.2016.08. 011

Yamada T, Aoyama H, Nishimura T, Iguchi M, Hendrasto M (2017) Volcanic eruption volume flux estimations from very long period infrasound signals. Geophys Res Lett 44:143-151. https://doi.org/ 10.1002/2016GL071047 